\title{
Expression of a recombinant branched chain $\alpha$-oxo acid dehydrogenase complex E2 (BCOADC-E2) in insect cells and its immunoreactivity to autoimmune sera
}

\author{
Sang-mi Lee, ${ }^{1}$ Soon-hee Ko, ${ }^{2}$ Jeong-eu Park ${ }^{3}$ \\ and Sang-hoon $\mathrm{Cha}^{1,4}$ \\ 1 Kangwon National University, College of Agriculture \& Life Sciences, Division of \\ Food and Biotechnology, Biotechnology Program, Chuncheon 200-701, Korea \\ 2 Kangdong Sungsim Hospital, Dept. of Cardiology, Seoul 134-701, Korea, \\ 3 Samsung Clinics, Center of Cardiovascular diseases, Seoul 135-230, Korea \\ 4 Corresponding author
}

Accepted 27 March 1998

Abbreviations: BCOADC, branched chain $\alpha$-oxo acid dehydrogenase complex; IDCM, idiopathic cardiomyopathy; PBC; primary biliary cirrhosis; $\mathrm{MOI}$, multiplicity of infection; $\mathrm{BMB}$, Boehringer Mannheim Biochemicals; O/N, overnight

\begin{abstract}
Keywords: autoantigen, branched chain $\alpha$-oxo acid dehydrogenase complex (BCOADC), idiopathic cardiomyopathy (IDCM), insect cells, primary biliary cirrhosis (PBC)
\end{abstract}

\section{Introduction}

Branched $\alpha$-oxo acid dehydrogenase complex, located in the matrix of mitochondria, is involved in the catabolism of the decarboxylation of alpha keto acids originated from transamination of the branched chain amino acids such as valine, isoleucine and leucine (Griffin et al., 1989), and composed of three catalytic subunits; branched $\alpha$ oxo acid decarboxylase (E1), dihydrolipoyl transaminase (E2) and dihydrolipoyl dehydrogenase (E3). Deficiency of this enzyme complex results in inherited maple syrup urine disease (MSUD) manifested by ketoacidosis, neurological disorders and mental retardation (Danner and Elsas, 1989). Clinical importance of the complex is further supported by that a E2 subunit of branched $\alpha$-oxo acid dehydrogenase comlpex (BCOADC-E2) is an autoantigen of primary biliary cirrhosis (PBC) (Fregeau et al., 1989) as well as idiopathic dilated cardiomyopathy (IDCM) (Ansari et al., 1991). The mammalian E2 subunit of the BCOADC contains three folded domains; a lipoyl-binding domain, an E3-binding domain and an inner core domain. The inner lipoyl domain which has lipoyl binding site is involved in the transacylation reaction and active site coupling (Lau et al., 1992), and contains autoepitope(s) recognized by sera from patients with PBC (Leung et al., 1995).

One of the most striking features of autoimmune diseases is the presence of autoantibodies in sera of the patients. In order to dissect the polyclonal nature of autoantibody responses in autoimmune patients, it is imperative to have a stable source of purified autoantigens. Furthermore, information on the structural characterization or protein sequencing studies using purified autoantigens can be used to investigate and map which parts of the autoantigen are the targets of the autoimmune responses, and such studies may elucidate whether immune res-ponses against certain autoantigens are involved in the pathogenesis of disease or are present secondary to pre-existing tissue damage. Therefore, generation of recombinant autoantigens either as full-length molecules or fragments is critical in the study of autoimmune responses and potentially applied in the accurate diagnosis or modulation of an autoimmune disease (Coppel et al., 
1989).

So far, numerous autoantigens have been produced in $E$. coli and used successfully for those purposes (Coppel et al., 1989). However, the stable production of full-length BCOADC-E2 by using prokaryotic expression system has had limited success due to severe degradation and low yield of the recombinant protein (personal communication with Dr. Patrick Leung at UC Davis and unpublished data from our laboratory), although there has been a report showing the expression of the molecule using pKK233-2 translation vector (Griffin et al., 1990). It is also interesting to note that sera from patients with IDCM react with a native form of BCOADC purified from fresh bovine tissues but not to a recombinant BCOADCE2 expressed in E. coli, implying that lacking post-translational modification of the molecule may affect the immunoreactive epitope recognized by IDCM sera.

Therefore, in order to determine whether a recombinant BCOADC-E2 expressed in eukaryotic expression system with post-translational modification may solve the limi-tation of autoantibody recognition seen in prokaryotic expression system, we subcloned the bovine full length BCOADC-E2 cDNA into a baculovirus transfer vector and produced the molecule in insect cells. So far several autoantigens including thyroid peroxidase have already been produced in insect cells and used successfully in the study of autoimmune responses (Whyte et al., 1995; Fan et al., 1996; Grennan et al., 1996; Strassburg et al., 1996).

Our results indicated that a recombinant bovine $\mathrm{BCO}$ ADC-E2 molecule is successfully produced in baculovirus expression system with the highest yield at 20 multiplicity of infection (MOI), and easily purified by an affinity isolation procedure. The affinity-purified recombinant BCOADC-E2 fusion protein was further used to investigate its immunoreactivity to autoimmune sera from patients with PBC or with IDCM.

\section{Materials and Methods}

\section{Construction of a recombinant baculovirus transfer vector}

Bovine full-length BCOADC-E2 cDNA in pKK233-2 (Griffin et al., 1990) was generously provided by Dr. Patrick Leung at University of California at Davis. The $1.4 \mathrm{~kb}$ cDNA insert was isolated by PCR amplification by using PCR primers containing appropriate restriction enzyme sites (sense primer: 5'-CCCGAATTCCAGGGCTGCAGACA TAGTCTT-3' and antisense primer: 5'-CCCGAGCTCTTTTA GATCTAGATGTTCTTT-3') at the condition of $95^{\circ} \mathrm{C} 1 \mathrm{~min}$, $55^{\circ} \mathrm{C} 2$ min and $72^{\circ} \mathrm{C} 2$ min for 35 cycles in Perkin Elmers Gene Amplifier 2400. The resulting PCR product was restricted with Eco RI and Sac I \{Boehreinger Mannheim Biochemicals (BMB), Germany\}. Thence, the BCOADC-
E2 gene fragment and pAcGHLT treated with the same set of restriction enzymes were ligated together using $\mathrm{T} 4$ DNA ligase $(\mathrm{BMB})$ overnight $(\mathrm{O} / \mathrm{N})$ at $16^{\circ} \mathrm{C}$, and $2 \mu \mathrm{l}$ of ligated DNA was introduced into $80 \mathrm{ml}$ of $\mathrm{DH}-5 \alpha$ electrocompetent cells in a $0.2 \mathrm{~mm}$ electrocuvette using Gene Pulser (BioRad, Richmond, CA) at $25 \mu \mathrm{F}, 200 \Omega$ and 2.5 kV.

\section{Transfection of pAcGHLT-BCOADC into insect cells}

pAcGHLT-BCOADC and linearized baculovirus Gold (Pharmigen, San Diego) were mixed and cotransfected into Spodoptera frugiperda (Sf) 9 insect cells (Pharmigen) using Lipofectin (Gibco BRL, Grand Island, NY) according to manufacturer's protocols. Briefly, $1 \times 10^{6}$ cells were seeded into each well of a 6 -well plate and grown at $27^{\circ} \mathrm{C}$ $\mathrm{O} / \mathrm{N}$. One and a half microgram of pAcGHLT-BCOADC and $500 \mathrm{ng}$ of linearized baculovirus were mixed in total $100 \mu \mathrm{l} \mathrm{Sf900} \mathrm{serum-free} \mathrm{medium} \mathrm{(Gibco} \mathrm{BRL)} \mathrm{and}$ combined with Lipofectin. This mixture was incubated for $15 \mathrm{~min}$ at RT. In the meantime, Sf9 cells in a 6-well plate were gently washed with $\mathrm{Sf} 900$ medium, and the DNA and Lipofectin mixture was added into cells following $\mathrm{O} / \mathrm{N}$ incubation at $27^{\circ} \mathrm{C}$. The plate was briefly washed with Grace's medium once and $2 \mathrm{ml}$ of Grace's medium with $10 \%$ fetal calf serum (FCS) and $10 \mu \mathrm{g} / \mathrm{ml}$ gentamycin was added (Summer and Smith, 1987). The culture supernatant was harvested after 4 days of incubation,.

\section{Plaque assay}

One million Sf9 cells were seeded into each well of a 6well plate at $27^{\circ} \mathrm{C}$ for $\mathrm{O} / \mathrm{N}$, and culture medium was aspirated. The culture supernatant from transfection assay was serially diluted with fresh Grace's medium with $10 \%$ FCS and $10 \mu \mathrm{g} / \mathrm{ml}$ gentamycin and added to each well. After $1 \mathrm{~h}$ incubation, Grace's medium in the 6well plate was completely removed, and $2 \mathrm{ml}$ of agarose overlay [50\% $2 \times$ Grace's medium with supplements (Gibco BRL), 20\% FCS, 5\% $\mathrm{dH}_{2} \mathrm{O}$ and $25 \%$ Bluo-gal agarose (Gibco BRL)] was gently poured onto each well, and the plate was further incubated for 4 days at $27^{\circ} \mathrm{C}$. Plaques were visualized by adding the agarose overlay containing additional $0.1 \%$ neutral red (Gibco BRL). The plaques were identified under the inverted light microscope on the following day and 11 well-separated plaques were isolated using sterile pasteur pipettes (Cha, 1996).

\section{Identification of positive recombinant baculovirus clones}

Half million Sf9 cells were seeded in each well of a 12-well plate and grown $\mathrm{O} / \mathrm{N}$. Thence, the cells were inoculated with the agarose cores containing viral particles and incubated for 4 days. Cells were harvested by brief centrifugation, and the resulting cell pellets were resuspended in $100 \mu \mathrm{l}$ SDS-PAGE sample buffer $(100 \mathrm{mM}$ Tris- $\mathrm{HCl}$, 
pH 6.8, 4\% SDS, 200 mM dithiothreitol, 20\% glycerol, $0.2 \%$ bromophenol blue, $2 \%$ mercaptoethanol) and boiled for $5 \mathrm{~min}$. Cellular proteins were separated by $10 \%$ SDSPAGE and transferred to nitrocellulose filter. The filter was blocked with $3 \%$ milk solution $(\mathrm{pH} \mathrm{7.0)}$ and incubated with 1:3,000 dilution of rabbit anti-BCOADC sera (generously provided from Dr. Aftab Ansari, Emory University, U.S.A.). Goat anti-rabbit IgG-conjugated with alkaline phosphatase (AP) (Sigma Chemicals, St. Louise, MO) was used as a secondary antibody and the immunoreactivity was visualized using NBT/BCIP substrate (BMS) (Surh et al., 1990). Low range M.W. marker (BioRad) was used as a M.W. standard.

\section{Determination of optimal MOI}

One million Sf9 cells were seeded into each well of a 6well plate for two hours at $27^{\circ} \mathrm{C}$ and the media were aspirated. Five hundred microliter of Grace's media containing $5 \times 10^{6}$ (MOI 5), $1 \times 10^{7}$ (MOI 10), $1.5 \times 10^{7}$ (MOI 15) or $2 \times 10^{7}$ (MOI 20) recombinant virus particles were added into each well and incubated for $1 \mathrm{~h}$. After removing viral suspensions, $1 \mathrm{ml}$ of fresh Grace's media was added, and the cells were grown for 4 days. Immunoblot was performed as described above except that mouse anti-BCOADC-E2 monoclonal antibody (5AC12C1, kindly provided from Dr. M. E. Gershwin at University of California at Davis, School of Medicine) was used as a primary antibody.

\section{Affinity purification of a recombinant BCOADC-E2 from insect cells}

Sf9 cells grown in T-75 culture flasks were infected with the recombinant virus at $20 \mathrm{MOI}$ for 4 days. In order to obtain cell lysate, the cell culture was centrifuged at $5,000 \mathrm{rpm}$ with GSA rotor for $10 \mathrm{~min}$ at $4^{\circ} \mathrm{C}$ and the resulting cell pellet was sonicated on ice for $2 \mathrm{~min}$ with 20 second intervals in the presence of $20 \mu \mathrm{M}$ phenylmethylsulfonyl fluoride (PMSF) (Sigma Chemicals). Finally the sonicated cell pellet was centrifuged at $10,000 \mathrm{rpm}$ in SS-34 rotor for $20 \mathrm{~min}$ at $4^{\circ} \mathrm{C}$, and the supernatant was utilized for the affinity purification of a recombinant BCOADC-E2 molecule by using either glutathioneagarose beads (Sigma Chemicals) (Smith and Johnson, 1988) or metal-binding resins (In Vitrogen, San Diego, CA) (Hedman et al., 1989).

\section{Determination of anti-BCOADC reactivity of autoimmune sera}

Sera from patients with PBC or with IDCM were provided from Dr. Patrick Leung at University of California at Davis and from Dr. Aftab Ansari at Emory University respectively. Additionally, sera from Korean patients with IDCM and other heart diseases were collected from Chuncheon Sungsim Hospital, Hallym University, School of Medicine and Samsung Clinics.
Binding specificity of PBC and DCM sera against a recombinant BCOADC-E2 was determined by ELISA and by immunoblot. Briefly, microtiter plates were coated with $10 \mu \mathrm{g} / \mathrm{ml}$ of an affinity purified BCOADC-E2 in coating buffer $(0.1 \mathrm{M}$ bicarbonate buffer, $\mathrm{pH} 9.6) \mathrm{O} / \mathrm{N}$ at $4^{\circ} \mathrm{C}$, and blocked with $1 \%$ BSA in PBS for $1 \mathrm{~h}$ at RT. Thence, the plates were washed with PBS-tween three times, and $100 \mu \mathrm{l}$ of appropriately diluted PBC and DCM sera were added into each well for $1 \mathrm{~h}$ at RT. One hundred $\mathrm{ml}$ of HRP-conjugated goat anti-human IgG (Fab') diluted at $1: 1,000$ in $1 \%$ BSA was added into each well, and $100 \mathrm{ml}$ of 2,2-azino-bis (3-ethylbenthia-zoline-6sulfonic acid) (ABTS) substrate in citrate buffer ( $\mathrm{pH} 4.0)$ was used as substrate. Absorbance at $405 \mathrm{~nm}$ of was then quantitated with an ELISA plate reader (Molecular Device Corp., Menlo Park, CA). Readings of O.D. at $405 \mathrm{~nm}$ were analyzed by student's t test and the data above $3 \times S D$ and $p<0.05$ from healthy volunteers considered positive. Immunoblot analysis was performed as described above, and the strips of nitrocellulose membrane were incubated with 1:500 dilution of PBC sera or 1:50 dilution of IDCM sera. Goat anti-human IgG-conjugated with AP (Sigma Chemicals) was used as a secondary antibody and NBT/BCIP (BMB) was used as a substrate.

\section{Results}

\section{Production of a recombinant BCOADC-E2 protein in insect cells}

cDNA fragment of bovine BCOADC-E2 with appropriate
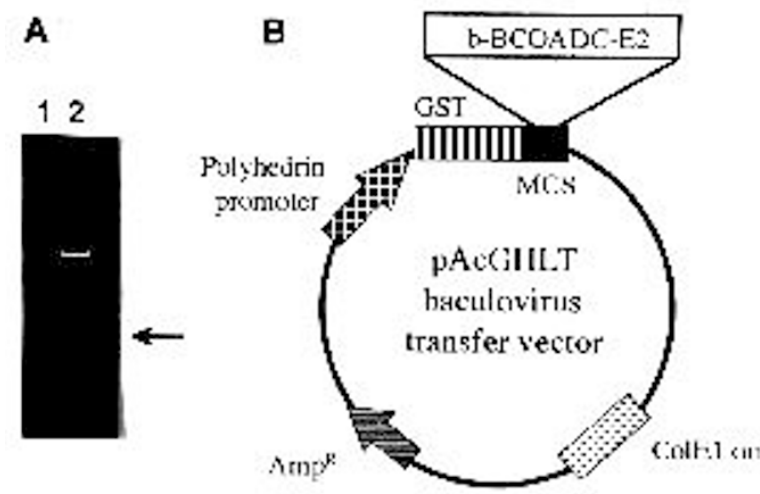

Figure 1. Cloning BCOADC-E2 CDNA into baculovirus transfer vector and a plasmid map. The $1.4 \mathrm{~kb}$ BCOADC-E2 cDNA insert was obtained by PCR amplification using primers containing appropriate restriction enzyme sites and a bovine full-length BCOADC-E2 CDNA in pKK233-2 as a template. The resulting PCR product was cloned into PACGHLT baculovirus transfer fusion vector and confirmed by $1 \%$ agarose gel electrophoresis (A). (lane 1: 1 kb ladder, lane 2: pAcGHLT treated with Eco RI/Sac I). Arrow indicates the BCOADC-E2 insert. The resulting plasmid construct is shown in (B). 


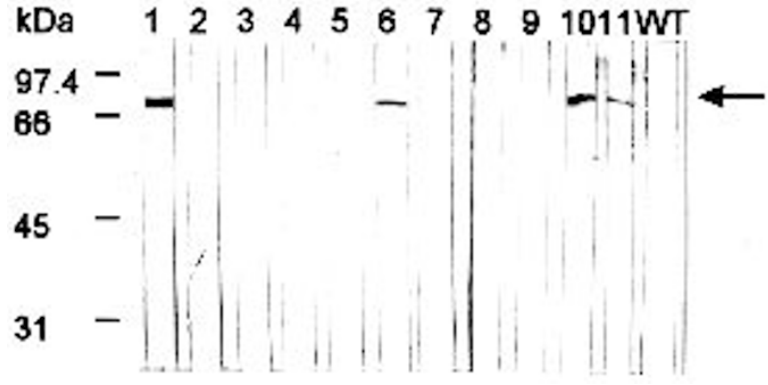

Figure 2. Identification of recombinant baculoviruses expressing a recombinant BCOADC-E2 protein by immunoblot. Plaque assay was performed as described in Materials and Methods, and 11 well-separated plaques were isolated. Half million Sf 9 cells were grown $\mathrm{O} / \mathrm{N}$ and cells were inoculated with viral particles for 4 days. The cellular proteins were separated by $10 \%$ SDS-PAGE and transferred to nitrocellulose filter. Rabbit anti-BCOADC sera and goat anti-rabbit IgG-conjugated with alkaline phosphatase (AP) were used as a primary and a secondary antibody respectively, and the immunoreactivity was visualized using NBT/BCIP substrate. Lane 1 - 11 : recombinant virus clones, lane 12: wild type baculovirus (negative control). Arrow indicates $72 \mathrm{kDa}$ recombinant $\mathrm{BCOADC}$-E2 fusion protein.

restriction sites at both $5^{\prime}$ and $3^{\prime}$ termini was obtained by PCR amplification and cloned into PAcGHLT baculovirus transfer vector (Figure $1 \mathrm{~A}$ and $\mathrm{B}$ ). The recombinant baculovirus transfer vector was introduced with linearized baculovirus DNA into Sf9 insect cells using lipofectin as described in Materials and Methods. pAcGHLT baculovirus transfer vector was used since the recombinant protein can be produced as a fusion protein containing GST and poly (His) tag, thereby, facilitating the purification of a foreign protein based upon specific affinity binding. After plaque assay, 11 recombinant baculovirus particles were randomly selected and used to infect Sf9 insect cells in 12-well plates. Immunoblot analysis was performed to determine the presence of a recombinant BCOADCE2 protein in insect cell lysates using rabbit anti-BCOADCE2 polyclonal antibody, and showed that $64 \%$ (7 out of 11 ) of the recombinant baculovirus clones expressed detectable amount of a bovine BCOADC-E2 fusion protein at $78 \mathrm{kDa}$ (Figure 2). Among them, \#1 recombinant baculovirus clone expressed the highest amount of the fusion protein, and thereby used for further experiments.

In order to determine the optimal MOI for the expression of the fusion protein, Sf9 insect cells were infected with the recombinant baculovirus at MOI 5, 10, 15 or 20 , and the cellular proteins were analyzed by immunoblot using mouse anti-BCOADC-E2 monoclonal antibody (5AC12C1) (Figure 3). Our results showed that $\mathrm{MOI} 20$ (Figure 3, lane 4) gave about 1.5 to 2.0 times higher yield of the fusion protein compared to other MOls in immunoblot semi-quantitatively analyzed by densitometry.

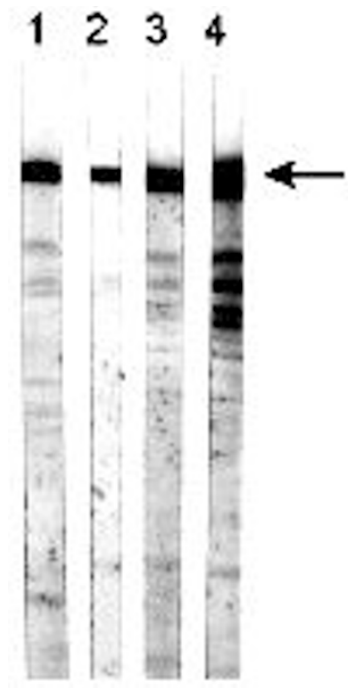

Figure 3. Determination of optimal MOI by immunoblot. One million Sf 9 cells were infected with $5 \times 10^{6}(\mathrm{MOI} 5), 1 \times 10^{7}(\mathrm{MOI} 10), 1.5 \times 10^{7}(\mathrm{MOI} 15)$ or $2 \times 10^{7}(\mathrm{MOI}$ 20) recombinant virus particles respectively, and the cellular proteins were analyzed by immunoblot as described in Materials and Methods except that mouse anti-BCOADCE2 monoclonal antibody was used as a primary antibody. Lane 1; MOI 5, lane 2; $\mathrm{MOI}$ 10, lane 3; MOI 15 and lane 4; MOI 20.

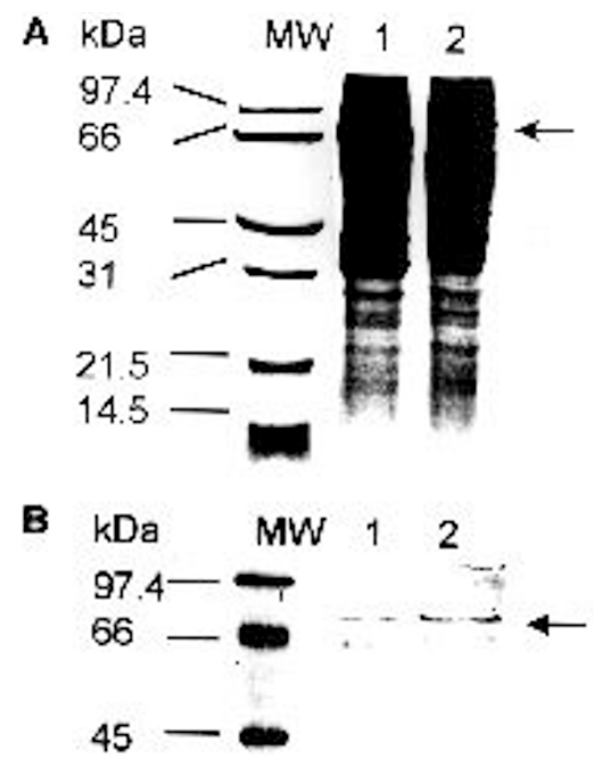

Figure 4. SDS-PAGE analyses of insect cell lysates and affinity-purified BCOADC-E2 protein. $S f 9$ cells were infected with the recombinant virus at $20 \mathrm{MOI}$ for 4 days. The cell culture was centrifuged and the resulting cell pellet was resuspended in SDS sample buffer followed by $10 \%$ SDS-PAGE analysis. The protein bands were visualized by Coomassie brilliant blue staining (A). For the affinity-purification of the recombinant fusion protein, the cell pellet was sonicated in the presence of $20 \mathrm{mM}$ phenylmethylsulfonyl fluoride (PMSF), and centrifuged. The supernatant was utilized for the affinity purification of a recombinant BCOADC-E2 by using either glutathioneagarose beads (lane 1) or metal-binding resins (lane 2) (B). Arrow indicates $72 \mathrm{kDa}$ recombinant BCOADC-E2 fusion protein. 


\section{Affinity purification of a recombinant BCOADC-E2 fusion protein}

Sf9 insect cells were infected with \#1 recombinant baculovirus clone at $\mathrm{MOI} 20$, and the cellular proteins were obtained from the cell pellet after treated with brief sonication as described in Materials and Methods. A recombinant bovine BCOADC-E2 fusion protein was purified with either glutathione agarose beads or metalbinding resins by taking advantage of the presence of GST or poly (His) tag at the N-terminal of the fusion protein (Figure 4). It is noteworthy that affinity purification of the protein with glutathione agarose beads always had strong contaminated protein bands at about $26 \mathrm{kDa}$, suggesting that some insect cell proteins bind to glutathione specifically. On the other hand, metal-binding resins gave a clean band of the recombinant molecule in SDS-PAGE with a yield of about $250 \mu \mathrm{g} / 10^{7}$ cells determined by a protein assay kit (from BioRad).

\section{Immunoreactivity of autoimmune sera against a recombinant BCOADC-E2 protein}

Sera from 9 patients with PBC, 39 patients with IDCM, 28 patients with other heart diseases and 16 healthy volunteers were tested for the anti-BCOADC-E2 reactivity by ELISA (Table 1). Our data showed that 4/9 (44\%) PBC sera gave strong positivity (approximately O.D. 0.8 at 405

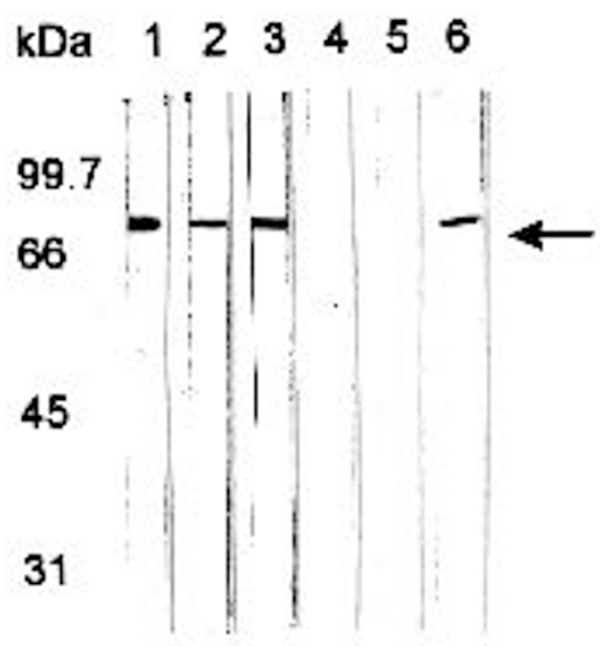

Figure 5. Immunoblot analysis showing anti-BCOADC-E2 reactivity of sera from patients with PBC. Sera from three patients with PBC (lane 1,2 and 3) and from two healthy volunteers (lane 4 and 5) were incubated with a recombinant BCOADC-E2 protein blotted onto nitrocellulose membrane. Anti-human $\lg G\left(F a b^{\prime}\right)_{2}$ conjugated AP and NBT/BCIP solution were used as a secondary antibody and substrate respectively. Lane 6 showed a positive control using mouse anti-BCOADC-E2 monoclonal antibody $(5 \mathrm{~A} 12 \mathrm{C} 1)$ and goat anti-mouse lgG-conjugated with alkaline phosphatase (AP). Arrow indicates $72 \mathrm{kDa}$ recombinant BCOADC-E2 fusion protein.
Table 1. Anti-BCOADC-E2 reactivity of autoimmune sera determined by ELISA.

\begin{tabular}{lcccc}
\hline & PBC $^{\mathrm{a}}$ & IDCM $^{\mathrm{b}}$ & $\begin{array}{c}\text { Other heart } \\
\text { diseases }^{\mathrm{b}, \mathrm{c}}\end{array}$ & $\begin{array}{l}\text { Healthy } \\
\text { volunteers }^{\mathrm{b}}\end{array}$ \\
\hline $\begin{array}{c}\text { No. of sera } \\
\text { tested }\end{array}$ & 9 & 39 & 28 & 16 \\
$\begin{array}{c}\text { No. of positive } \\
\text { reactivity } \\
\text { \% of positive } \\
\text { reactivity }\end{array}$ & 4 & 3 & 4 & 0 \\
\hline
\end{tabular}

\footnotetext{
a Used at 1:100 dilution

${ }^{\mathrm{b}}$ Used at 1:40 dilution

${ }^{c}$ No autoimmune diseases

${ }^{d}$ Reactivity was considered positive if the O.D.405 value was $3 \times S D$

above and $p<0.05$ compared to data obtained from healthy volunteers.
}

$\mathrm{nm} 0.8$ at $1: 100$ dilution), and $3 / 39$ (12.8\%) IDCM sera were positive with O.D. reading at $405 \mathrm{~nm}$ were varied from 0.3 to 0.5 at $1: 40$ dilution, which are much weaker than data obtained from PBC sera. However, sera form patients with other heart diseases that used as negative controls also showed $14.2 \%$ of positive reactivity to the protein suggesting that the positive reactivity seen in IDCM sera is not specific. Serum titer of PBC and IDCM, 1:100 and 1:40 respectively, was chosen since this titer has previously been used to determined the anti-BCOADCE2 reactivity without much background problem (Ansari et al., 1994; Leung et al., 1995). Anti-BCOADC-E2 reactivity by autoimmune sera also confirmed by immunoblot (Figure 5). Sera from three patients with PBC at 1:100 dilution (lane 1, 2 and 3), but not sera from healthy normal volunteers (lane 4 and 5), showed nice reactivity to a recombinant fusion protein. Thirty nine IDCM sera at 1:40 dilution were also tested by immunoblot, but none of them have any significant anti-BCOADC-E2 reactivity compared to normal sera at the same dilution (data not shown).

\section{Discussion}

It has been known that approximately $60 \%$ of patients with PBC (Fregeau et al., 1989; Mackay and Gershwin, 1990 ) and $20 \%$ of patients with IDCM (Ansari et al., 1991) have autoantibodies reacting with BCOADC-E2 in their sera, and so far, the presence of the autoantibodies has been determined based upon positive reactivity by immunoblot or ELISA using either crude mitochondrial extracts or biochemically purified BCOADC molecule from bovine tissues. In order to provide more specific detection of immunoreactivity to BCOADC-E2 in autoimmune sera, we have tried several $E$. coli expression vectors such as pGEX, pGEM, or TrcHis to express 
bovine BCOADC-E2 molecule with only limited success due to the low expression yield and severe degradation of the recombinant protein (data unpublished) suggesting that genetic modification of the molecule or alternative expression system is required. In this study, we have expressed a recombinant BCOADC-E2 in insect cells using baculovirus expression system, and pAcGHLT baculovirus transfer vector was used because this vector enables us the simple affinity purification of the recombinant protein since a foreign protein is expressed as a fusion protein with GST and polyhistidine tag encoded by the vector. In results, we found it interesting that affinity purification of the molecule using GST agarose beads always produced strong extra protein bands at approximately $26 \mathrm{kDa}$ size of unknown identity. In contrast to our results, the isolation of a cystic fibrosis transmembrane conductance regulator (CFHR) recombinant protein using the same purification procedure didn't show these extra protein bands (Sorscher and Sommerfelt, 1995). It didn't seem likely that the extra protein bands were derived from the degradation of a GST:BCOADC-E2 fusion protein since the protein bands at low molecular weight didn't recognized by either anti-BCOADC-E2 monoclonal antibody or anti-GST polyclonal antibody in immunoblot. In fact, our experience with a recombinant TGF- $\beta$ fusion protein produced in insect cells using the same baculovirus transfer vector also had the same $26 \mathrm{kDa}$ extra protein bands after GST affinity purification (unpublished data), indicating that insect cell lysate may contain protein fractions that specifically bind to GST agarose beads. This assumption is further supported by that using metalchelating resins in an affinity purification step completely removed the protein contamination. Although the nature of the contaminant protein is not yet known, we assume that it may be a carbonic anhydrase isozyme III since the enzyme has a similar molecular weight ( $26 \mathrm{kDa})$ as well as specifically binds to glutathione by forming disulfide bonds (Carbiscol and Levine, 1996).

Titer and percentage of IDCM sera that contain autoantibodies against BCOADC-E2 varies 1:20 to 1:400 and 20 to $60 \%$ respectively depending on different studies, and it has been reported that immunodominant epitope is localized at amino acid sequences $116-134$ of the molecule by using synthetic peptide fragments although no one has been replicated the results yet (Ansari et al., 1994). Whereas, it has been confirmed that conformational epitope(s) spanning amino acid sequence 1 to 227 of BCOADC-E2 is recognized by sera from patients with PBC (Leung et al., 1995), suggesting that the nature of autoantibody response to BCOADC-E2 between PBC and IDCM may be different. This assumption is further supported by that PBC sera usually have much high titer (1:500) compared to IDCM sera. In our results, a recombinant BCOADC-E2 fusion protein expressed in insect cells was strongly recognized by PBC sera (44\%), although percentage of positivity is slightly lower than previously published data (Fregeau et al., 1989). We believe that this is due to the low number of PBC sera we tested. In contrast to $\mathrm{PBC}$ sera, our recombinant BCOADC-E2 fusion protein did not recognized by IDCM sera. It is difficult to understand why the IDCM sera did not react with the fusion protein since there is no report so far that autoantigens produced in insect cells failed to react with autoantibodies. It may possible that bovine origin of BCOADC-E2 is suitable for the detection of anti-self reactivity from IDCM patients but this possibility is highly unlikely since the first notification of anti-BCOADCE2 reactivity in IDCM sera was identified by using bovine heart mitochondria extract. It is also possible that posttranslational modification specific to mammalian cells are important in the formation of epitope that recognized by IDCM sera, or lack of lipoylation or presence of GST fusion part may interfere the binding of the autoantibodies from patients with IDCM. In this context, there are inter-esting findings that the anti-BCOADC-E2 reactivity using crude beef heart mitochondrial preparation originally, dramatically reduced by a few rounds of freezing and thawing of IDCM sera implying that the autoantibodies in IDCM sera are very labile, and a recombinant BCOADC-E2 expressed in E. coli has never showed a good binding specificity in both immunoblot and ELISA (personal communication with Dr. Aftab Ansari at Emory University, School of Medicine, GA). These findings have not seen in sera from patients with $\mathrm{PBC}$, and it has also been known that absence of lipoic acid moiety in a recombinant BCOADC-E2 did not affect the binding of autoimmune PBC sera (Griffin et al., 1990). Since the biochemically purified BCOADC which has been used to determined immunoreactivity of IDCM sera in ELISA so far contained other mitochondrial proteins, predominantly pyruvate dehydrogenase complex-E2 (author's unpublished data), we believe that classification of BCOADC-E2 as an authentic autoantigen in IDCM may need to be reevalu-ated, and presence of anti-BCOADC-E2 reactivity in sera from patients with heart diseases may be not a good diagnostic index for IDCM as shown in Table 1.

In conclusion, the bovine BCOADC-E2 protein was successfully expressed in Sf9 insect cells using baculovirus expression system, and the resulting fusion protein was utilized to detect the presence of anti-BCOADC-E2 autoantibody response in PBC. In contrast, IDCM sera didn't reacted with a recombinant BCOADC-E2 fusion protein, thereby, it is inappropriate to use a recombinant BCOADC-E2 protein expressed in insect cells for determination of immunoreactivity of IDCM sera, if there is any binding specificity.

\section{Acknowledgment}

This study was supported by the Academic Research 
Fund (GE96-7) of the Ministry of Education, Republic of Korea.

\section{References}

Ansari, A. A., Wang, Y. C., Danner, D. J., Gravanis, M. B., Mayne, A., Neckelmann N., Sell K. W. and Herskowitz A. (1991) Abnormal expression of histocomaptibility and mitochondrial antigens by cardiac tissue from patients with myocarditis and dilated cardiomopathy. Am. J. Pathol. 139: 337-348

Ansari, A. A., Neckelmann, N., Villinger, F., Leung, P., Danner, D. J., Brar, S. S., Zhao, S., Gravanis, M. B., Mayne, A., Gershwin, M. E. and Hersko-witz, A. (1994) Epitope mapping of the branched $\alpha$-keto acid dehydro-genase dihydrolipoyl transacylase (BCKD-E2) protein that reacts with sera from patients with idiopathic dilated cardiomyopathy. J. Immunol. 153: 4754-4765

Carbiscol, E. and Levine, R. L. (1996) The phosphatase activity of carbonic anhydrase III is reversibly regulated by glutathiolation. Proc. Natl. Acad. Sci. USA 93: 4170-4174

Cha, S. (1996) Expression of a human monoclonal lgG Fab molecule in Sf9 insect cells Korean J. Immunol. 18: 393-401

Coppel, R. L., Gershwin, M. E. and Sturgess, A. D. (1989) Cloned auto-antigens in the study and diagnosis of autoimmune diseases. Mol. Biol. Med. 6: 27-34

Danner, D. J. and Elsas, L. J. (1989) In The Metabolic Basis of Inherited Disease (Scriver CR, Beaudet AL, Sly WS, Valle D, eds), 6th Edn., pp. 671-692, McGraw-Hill Publishers, New York

Fan, J. L., Patibandla, S. A., Kimura, S., Rao, T. N., Desai, R. K., Seetha-ramaiah, G. S Kurosky A. and Prabhakar, B. S. (1996) Purification and characterization of a recombinant human thyroid peroxidase expressed in insect cells. J. Autoimmunity 9 : 529-536

Fregeau, D. R., Davis, P. A., Danner, D. J., Ansari, A., Coppel, R. L., Dickson, E. R. and Gershwin, M. E. (1989) Antimitochondrial autoantibodies of primary biliary cirrhosis recognize dihydrolipoamide acetyltransferase and inhibit enzyme function of the branched chain $\alpha$-keto acid dehydrogenase complex. J. Immunol. 142: 3815-3820

Grennan, J. F., Wolstenholme, A., Fowler, S., Smith, S., Ziemnicka, K., Bradbury, J., Furmaniak, J. and Rees Smith, B. (1996) High-level expres-sion of recombinant immunoreactive thyroid peroxidase in the High Five insect cell line. J. Mol. Endocrinol. 17: $165-174$

Griffin, T. A., Lau, K. S. and Chuang, D. T. (1989) Characterization and conservation of the inner E2 core domain structure of branched chain $\alpha$-keto acid dehydrogenase complex from bovine liver: construction of cDNA clone encoding the entire transacylase (E2b) precursor. J. Biol. Chem. 263: 14008-14014

Griffin, T. A., Wynn, R. M. and Chuang, D. T. (1990) Expression and assembly of mature apotransacylase (E2b) of bovine branched chain $\alpha$-keto acid dehydrogenase complex in Escherichia coli : Demonstration of transacylase activity and modification by lipoylation. J. Biol. Chem. 265: 12104-12110.

Hemdan, E. S., Zhao, Y., Sulkowski, E. and Porath, J. (1989) Surface topology of histidine residues: A facile probe by immobilized metal ion affinity chromatography. Proc. Natl. Acad. Sci. USA 86: 1811-1815

Lau, K. S., Herrings, W. J., Chuang, J. L., McKean, M., Danner, D. J., Cox, R. P. and Chuang, D. T. (1992) Structure of the gene encoding dihydrolipoyl transacylase (E2) of human branched chain $\alpha$-keto acid dehydrogenase complex and characterization of an E2 pseudogene. J. Biol. Chem. 267: 24090-24096

Leung, P. S. C., Chuang, D. T., Wynn, R. M., Cha, S., Danner, D. J., Ansari, A., Coppel, R. L. and Gershwin, M. E. (1995) Autoantibodies to BCOADC-E2 in patients with primary biliary cirrhosis recognize a conformational epitope. Hepatol. 22: 505-513

Mackay, I. R. and Gershwin, M. E. (1990) Primary biliary cirrhosis: consi-derations on pathogenesis based on identification of the M2 autoantigens. Springer Semin. Immunopathol. 12: 101-109

Smith, D. B. and Johnson, K. S. (1988) Single-step purification of poly-peptides expressed in Escherichia coli as fusions with glutathione S-transferase. Gene 67: 31-40

Sorscher, E. J. and Sommerfelt, M. A. (1995) In Methods in Molecular Biology Vol. 39, Baculovirus expression protocols. (Chistopher, D. R., Ed.), pp. 337-348, Humana Press Inc., New Jersey

Strassburg, C. P., Alex, B., Zindy, F., Gerken, G., Luttig, B., Meyer zum Buschenfelde, K. H., Brechot, C. and Manns, M. P. (1996) Identification of cyclin A as a molecular target of antinuclear antibodies. J. Hepatol. 25: 859-866

Summers, M. D. and Smith, G. E. (1987) In A Manual of Methods for Baculovirus Vectors and Insect Cell Culture Procedures. p. 1-56, Texas Agriculture Experimental Station, Texas

Surh, C. D., Ansari, A. and Gershwin, M. E. (1990) Structural requirement for autoreactivity on human pyruvate dehydrogenase-E2, the major auoantigen of primary biliary cirrhosis; implication for a conformational autoepitope. J. Immunol. 144: 33673374

Whyte, J., Earnshow, W. C., Champoux, J. J., Parker, L. H., Stewart, L., Hall, N. D. and McHugh, N. J. (1995) Detection of anti-topoisomerase I antibodies using a full length human topoisomerase I recombinant protein purified from a baculovirus expression system. Clin. Exp. Immunol. 100: 214-218 